\title{
Darkness as an Anthropological Space: Perspectives Induced by Psalms 88 and 139 on the Themes of Death, Life and the Presence of $\mathrm{YHWH}^{1}$
}

\author{
LodeWyK SuTton (UNIVERSity OF THE Free STATE)
}

\begin{abstract}
In this article an intertextual comparison is made between Pss 88 and 139 on the theme and use of the concept of "darkness." In the metanarrative of the shape and shaping of the Psalter, these two psalms are counterpointed to each other. Psalm 88 is traditionally viewed as an individual lament of a person who is sick, dying or facing death. Darkness is a prominent theme in this psalm, with a situation of hopelessness in the exilic period. In contrast, darkness is portrayed differently in Psalm 139, where a different message for the post-exilic period is presented in the meta-narrative. Psalm 139, from the perspective of YHWH as creator, can be interpreted as a ritual or individual meditative confession after some sort of possible trial period. To gain a better understanding on the use of darkness in these two psalms, the theme is analysed from the perspective of anthropological space.
\end{abstract}

KEYWORDS: Psalm 88, Psalm 139, anthropological space, darkness, death, life, presence of YHWH.

\section{A INTRODUCTION}

In canon-critical research on the shape and shaping of the psalter, the metanarrative that is presented by scholars as the story of the psalter begins with king David and his reign over the united kingdom of Israel as it is presented in Book I (Pss 1-41) of the psalter. ${ }^{2}$ The reign of David and that of Solomon are further

* Article submitted: 2019/03/04; peer reviewed: 2019/05/17; accepted: 2019/07/19. Lodewyk Sutton, "Darkness as an Anthropological Space. Perspectives Induced by Psalms 88 and 139 on the themes of Death, Life and the Presence of YHWH," OTE 32 no. 2 (2019): 556-577. DOI: https://doi.org/10.17159/2312-3621/2019/v32n2a16.

1 This article is dedicated to Prof Phil J. Botha. His contribution on wisdom and the Psalms serves as an example to all academics. As a former student of Prof Botha, I and many other students were guided along the path of Hebrew, the Psalms, and the Old Testament in general. His love and use of social-scientific research in the Psalms also guided me in my own research. Thank you, Prof Botha, for sharing your knowledge and wisdom.

2 For a further study on the topic of canonical-critical research in the Book of Psalms and the topic of the shape and shaping of the Psalter and the meta-narrative of the Psalter, see Nancy deClaissé-Walford, Reading from the Beginning. The Shaping of the 
recounted in Book II (Pss 42-72) of the Psalter. The destruction of the divided northern (Israel) and southern kingdoms (Judah) by the Assyrians and the Babylonians is described in Book III (Pss 73-89). The time, terror and struggles of the exiles, especially in Babylon where the nation of Israel needs to find identity and meaning in this period and under these circumstances, are described in Book IV (Pss 90-106). The return to Jerusalem and the formation of the new Israel with the new king (the new David) and with God as the sovereign God of Israel, is seen in Book V (Pss 107-150) of the Psalter.

In this meta-narrative, Ps 88 is near the end of Book III in the Psalter. Ps 88 is traditionally viewed as an individual lament of a person who is sick; ${ }^{3}$ however the psalm should rather be viewed as one that depicts a situation of being threatened by death. ${ }^{4}$ In the psalm different metaphors are used to describe death and the underworld, with the theme of darkness being prominent. According to Mare, ${ }^{5}$ Ps 88 differs from a typical lament due to the fact that the expression of trust and praise are lacking in this psalm. Ps 88 is almost wholly composed of complaints (vv. 4-19 [3-18]) and only small parts of the psalm

Hebrew Psalter (Macon, GA: Mercer University Press, 1997), 1-14; Nancy deClaisséWalford, Introduction to the Psalms. A Song from Ancient Israel (St. Louis, MO: Chalice, 2004); Nancy deClaissé-Walford, "The Canonical Approach to Scripture and the Editing of the Hebrew Psalter," in The Shape and Shaping of the Book of Psalms. The Current State of Studies (ed. Nancy deClaissé-Walford; AIL 20; Atlanta, GA: SBL, 2014), 1-11; Nancy deClaissé-Walford, "The Meta-Narrative of the Psalter," in The Oxford Handbook of the Psalms (ed. William P. Brown; Oxford: Oxford University Press, 2014), 363-376; Nancy deClaissé-Walford, Rolf A. Jacobson and Beth LaNeel Tanner, The Book of Psalms (NICOT; Grand Rapids, MI: Eerdmans, 2014), 21-38; David M. Howard, The Structure of Psalms 93-100 (BJSUCSD 5; Winona Lake, IN: Eisenbrauns, 1997), 1997), 1-18; J. Clinton McCann Jr., "The Shape and Shaping of the Psalter: Psalms in Their Literary Context," in The Oxford Handbook of the Psalms (ed. William P. Brown; Oxford: Oxford University Press, 2014), 350-362; Erich Zenger, "The Composition and Theology of the Fifth Book of Psalms, Psalms 107145," JSOT 80 (1998): 77-102; and the various contributions in Erich Zenger (ed.), The Composition of the Book of Psalms (BETL 238; Leuven: Peeters, 2010).

3 The typical structure of a lament is that of invocation, complaint, petition, expression of trust, and expression of praise; cf. William H. Bellinger Jr., Psalms. A Guide to Studying the Psalter (2 ${ }^{\text {nd }}$ ed.; Grand Rapids, MI: Baker Academic, 2012), 5051.

4 Charles H. Briggs and Emilie G. Briggs, The Book of Psalms, Vol 2 (ICC; Edinburgh: T\&T Clark, 1969) 244, classify the psalm as a national lament of extreme distress in the time of the exile. According to Benjamin J. Segal, A New Psalm. The Psalms as Literature (Jerusalem: Gefen, 2013), 413 this must be viewed as the saddest of the psalms as there is no light or hope and only darkness. It is a "call to God that begins and ends in darkness."

5 Leonard P. Maré, "Facing the Deepest Darkness of Despair and Abandonment: Psalm 88 and the Life of Faith," OTE 27 (2014): 177-188 (180). 
consist of invocation (vv. 2 [1], 10 [9], 14 [13], 15 [14]) and petition (v. 3 [2]), ${ }^{6}$ leaving the psalm in a state of hopelessness. In the story of the meta-narrative, a state of total hopelessness and darkness during the period of exile is portrayed. Thornhill remarks on this state of hopelessness in exile that "Psalm 88 provides the uneasy transition from the (false) confidence of the Davidic rulers and Jerusalem to their subsequent abandonment by YHWH..."?

In contrast, the theme of darkness is portrayed differently in Ps 139, where a different message for the post-exilic period in the meta-narrative is presented. Psalm 139 may be understood in terms of a meditative confession by a poet who meditates on being human in the presence of YHWH, after some kind of possible trial period (juridical process, torment by enemies, or a post-exilic experience, after the return from the Babylonian exile). ${ }^{8}$ As part of Book V, Ps 139 follows Ps 138 which is viewed as a response to the situation of need that has already been stated in Ps 137 and the rest of Pss 139-145. The individual (representative in the meta-narrative of Israel) is portrayed in a context of need and therefore the psalmist seeks to be delivered from the threat of the enemies. The reason for this search for deliverance is to restore and strengthen the relationship with YHWH, and in the meta-narrative the psalm becomes part of a process of restoration for the nation after the time of exile. ${ }^{9}$ A value system of universal space (as seen in Ps 139:7-12) and restricted time is important after the exile. ${ }^{10}$ The time element is especially evident and incorporated in the LXX text of Ps 139. The theme of

6 deClaissé-Walford, "Meta-Narrative," 371.

7 Chadwick A. Thornhill, “A Theology of Psalm 88," EvQ 87 (2015): $45-57$ (54).

8 Cf. Hans-Joachim Kraus, Psalms 60-150. A Commentary (trans. Hilton C. Oswald; CC; Minneapolis, MN: Augsburg Fortress, 1989), 511; Erhard S. Gerstenberger, Psalms Part 2 and Lamentations (FOTL 15; Grand Rapids, MI: Eerdmans, 2001), 405406; Samuel Terrien, The Psalms. Strophic Structure and Theological Commentary (ECC; Grand Rapids, MI: Eerdmans, 2003), Eric Peels, "I Hate Them with Perfect Hatred (Psalm 139:21-22)," TynBul 59 (2008): 35-51 (42); and Leonard P. Maré, “Creation Theology in Psalm 139," OTE 23 (2010): 693-707 (697).

9 Cf. Frank-Lothar Hossfeld and Erich Zenger, Psalms 3: A Commentary on Psalms 101-150 (trans. Linda M. Maloney; Hermeneia; Minneapolis, MN: Fortress, 2011), 6; W. Dennis Tucker Jr., Constructing and Deconstructing Power in Psalms 107-150 (AIL 19; Atlanta, GA: SBL, 2014), 124-125; and W. Dennis Tucker Jr., "The Role of the Foe in Book 5: Reflections on the Final Composition of the Psalter," in The Shape and Shaping of the Book of Psalms. The Current State of Scholarship (ed. Nancy deClaissé-Walford; AIL 30; Atlanta, GA: SBL, 2014), 179-191 (188).

10 Cf. Phil J. Botha, "Psalm 108 and the Quest for Closure," OTE 23 (2010): 574-596. Botha provides a number of notes on how the psalms in Book V provide closure after the period of exile for Israel. 
hope and restoration is thus the focus of Book V after the time of the Babylonian exile. $^{11}$

To gain a better understanding on the use of darkness in these two psalms, the theme is analysed from the perspective of anthropological space. From this perspective, an intertextual comparison of 'darkness as a space' in Pss 88 and 139 is made in regard to the themes of death, life and the presence of YHWH so as to indicate the important function darkness as a space plays in the metanarrative of the psalter. ${ }^{12}$

\section{B SPACE AND ANTHROPOLOGY AS A POINT OF DEPARTURE}

\section{Ancient Near Eastern spatial orientation}

To help the interpreter in the process of a bodily interpretation, and to understand darkness as a space, one needs to take into account "literary" spatial theory.

11 Terrien, $P$ salms, 880 proposes that Ps 139 was written by a disciple who was wellknown in Jeremiac literature at the end of the kingdom of Judah, around 607-587 BCE and that the psalm reflects a situation of national agony. The enemy, then, is Babylonian tyrants, Judahite traitors, or even Judahite patriots. There is no evidence for this argument in the text and therefore it cannot be followed. Mitchell Dahood, Psalms III: 101-150 (AB; Garden City, NY: Doubleday, 1970), 284 ascribes the psalm to a religious leader who has been accused of idol worship. He dates the psalm around the seventh century BCE due to the Aramaisms. His argument is based on certain words that, according to Leslie C Allen, Psalms 101-50, revised (WBC 21; Nashville, TN: Thomas Nelson, 2002), 326 should rather be viewed as post-exilic forms. Those who identify wisdom elements in the text follow a post-exilic dating (Allen, Psalms 101$150,327)$. The post-exilic redactors of the psalter attributed the psalm to David and called it "for the choir leader," but it is unclear who the author for the psalm may be (Terrien, Psalms, 875). The author directs the prayer towards YHWH and uses first person singular for the one praying and second person singular for addressing the divine. The one praying reveals him- or herself as a "person scrutinized" (Gerstenberger, Psalms, Part 2, 401). Further, one can only construct subjective deductions as to who the author might have been or could have represented. A probable dating would be to an exilic or post-exilic community in Judah or the Diaspora; cf. Arnold A. Anderson, The Book of Psalms (73-150) (NCB; Grand Rapids, MI: Eerdmans, 1981), 905; Gerstenberger, Psalms, Part 2, 406; Maré, "Creation Theology in Psalm 139," 697).

12 According to Gert T.M. Prinsloo, Hebreeus is Kinderspeletjies. Volume 2. Die Analise en Interpretasie van Bybels-Hebreeuse tekste (Pretoria: Universiteit van Pretoria, 2008), 52 and Paul E. Koptak, "Intertextuality," in Dictionary of the Old Testament: Wisdom, Poetry and Writings (ed. Tremper Longman III and Peter Enns; Nottingham: Inter-Varsity Press, 2008), 325-332, an intertextual analysis makes the connection between a specific text and other similar texts. In a Biblical context, the question arises as to whether a specific text shows any connection to other Biblical and/or non-Biblical texts. 
According to Gottwald, ${ }^{13}$ literary studies are moving in the "direction of freedom from the domination of history and religion and toward the opening up of methodological space to explore new avenues of access to the Hebrew Bible." In this process one is studying a literary text where, according to Prinsloo, ${ }^{14}$ these texts are "constructed, produced or represented by means of words." "Literary" space can be understood in studying a text in the context of narrative space or theory, social space and ancient Near Eastern spatial orientation. For the purpose of this article, the ancient Near Eastern orientation or rather worldview(s) play(s) an important part.

When it comes to time and space, these are, according to Wyatt, ${ }^{15}$ culturally learned and they determine one's everyday understanding of life and of one's worldview - whether one knows it or not - directly or indirectly. For ancient Near Eastern people, this worldview is part of their understanding and their orientation. ${ }^{16}$ In the Old Testament, the spatial orientation of the worldview that is presented can be described on a vertical and a horizontal axis. The vertical axis that moves from up to down can be seen as heaven (up, the traditional home of YHWH or God), earth (middle, traditional home of humans), and the underworld or Sheol (down or under, where YHWH is not present - Exod 20:4), as seen in Ps 139:8. To move up is positive, to move down is considered negative. The horizontal axis as described in Ps 139:9 is from where the sun rises to where it sets (east to west), where the earth is considered to be at the centre of the horizontal sphere. Heaven, earth and Sheol are enclosed in a sphere called the cosmic ocean. At the ends of the earth (Isa 41:4), which is the extreme circular horizon (Job 26:10), the mountains that support the heavens can be found. One reads that it was at the foundations, at the very depths of these mountains that the battles between YHWH and chaos occurred (Ps 18:7, 15). These boundaries of east and west are also seen as the extreme boundaries between light (where the sun rises) and darkness (where the sun sets), where light is viewed as a positive space and darkness as a negative space. The gates to the underworld

13 Norman Gottwald, The Hebrew Bible. A Socio-Literary Introduction (Philadelphia, PA: Fortress, 1987), 22.

14 Gert T. M. Prinsloo, "Place, Space and Identity in the Ancient Mediterranean World: Theoretical Considerations and Practical Application with Reference to the Book of Jonah," in Constructions of Space V: Place, Space and Identity in the Ancient Mediterranean World (ed. Gert T. M. Prinsloo and Christl M. Maier; LHBOTS 576; London: T\&T Clark, 2013), 3-25 (5).

15 Nicolas Wyatt, Space and Time in the Religious Life of the Near East (Sheffield: Sheffield Academic Press, 2001), 33.

16 It is important to understand that within the ancient Near Eastern worldview there are multiple views: it is not a closed systematic system, hence it would be better to say "worldviews" rather than "worldview." Also these worldviews are theoretical reconstructions of the ancient Near Eastern worldviews and their spatial orientations (Prinsloo, "Place, Space and Identity," 9). 
where the sun rises in the east and sets in the west are also found at these extreme horizons, according to Ps $65: 8 .{ }^{17}$ According to this worldview, there is a mountain at the centre, where the horizontal and the vertical spheres cross. This mountain is viewed as the cosmic centre of the universe: it is considered as the temple mountain where one would be in direct contact with God who sits on a throne in heaven directly above the holiest area of the temple. To be in the temple, therefore, would be to be in direct contact with YHWH and in the presence of God; it would be as if one were standing in Heaven. The opposite of this is to be in Sheol where YHWH is not present, or to move as far away from the temple mount as possible, with the extreme being the furthest ends of east and west, moving away from God into darkness, into negative space. ${ }^{18}$

The vertical and the horizontal axes are not the only important elements for the ancient Near Eastern orientation. The directions of east, west, south and north must also be plotted on these axes. For the ancient Near Eastern person, the front of the person is east and is the place where the sun rises in the morning, indicating a new day or beginning. If one prays or directs oneself towards God, an eastern direction or orientation aligns one with God. East is thus viewed as the primary orientation in the ancient Near East. The opposite of east, which is the front, is the west, which is considered to be at one's back and also the space where the sun sets at the end of the day. The direction of the rising and setting sun is viewed as an image of totality as with east and west. The entrance to the underworld is considered to be in the west, in the direction of the sea that is situated in the west, called the Western Sea, Great Sea or today the Mediterranean Sea. If the front is east then north is on the left or on a person's left-hand side. North is not considered as a direction with positive connotations, as that is the direction from which enemy invaders usually come. North is also associated with the mountains where the gods are. An example of this is the Canaanite god, Baal Zaphon, who lives on the mountain, dshebe, later called Mons Casius (in Syria). Ps 121 and Isa 14:13 also refer to the gods on the mountains and God's home that can be found in the north. If left is north, then south is on a person's right-hand side. The desert lies to the south (a place where God is found or comes from - Deut 33:2; Hab 3:3; and or where evil is found). ${ }^{19}$

17 Lodewyk Sutton, "The Rising of Dawn - An Investigation of the Spatial and Religious Background of 'Dawn' in Psalm 139:7-12,' JSem 20 (2011): 546-561 (555556); Hossfeld and Zenger, Psalms 3, 540-541; Wyatt, Space and Time, 40; Prinsloo, "Place, Space and Identity," 9; and Klaus Seybold, Introducing the Psalms (trans. R. Graeme Dunphy; Edinburgh: T\&T Clark, 1990), 194.

18 Sutton, "The Rising of Dawn," 557; cf. also Hossfeld and Zenger, Psalms 3, 541; Prinsloo, "Place, Space and Identity," 10 and Wyatt, Space and Time, 40.

19 Sutton, "The Rising of Dawn," 557; cf. also Joel F. Drinkard, "East," ABD 2: 248; Idem, "North," $A B D$ 4: 1135-1136; Idem, "South," $A B D$ 6: 171; Idem, "West," $A B D$ 6: 908; and Brevard S. Childs, "Orientation," IDB 3: 608. 
The temporal dimension functions as an important element in the horizontal orientation of east to west for the ancient Near East. Wyatt ${ }^{20}$ explains the temporal dimension as "the remote past is where mythic events 'happened', providing patterns for present belief and behaviour. Rituals re-actualise ('represent') the mythic realities now. Mythic time is said to be 'the eternal present', because it determines the present." This means that for the ancient Near Eastern person, in front of them would be east, and at their back would be west, with north and south on their left- and right-hand sides, respectively. For them east would be considered the past, and west the future. In this temporal dimension one walks into the future with one's back towards the future (west), focusing on that which is in the front, the past (east). The reason for this orientation is that the past influences your present life and therefore also your future. Past problems are therefore addressed by looking at the past to find resolution for the present and the future. The ancient Near Eastern person therefore has a very strong focus on the present that is guided by the past, and leading them into the future. ${ }^{21}$

For the purposes of this article it is the downward movement, or the vertical space, that is important - the perception of the underworld or Sheol. This space is viewed as negative and the presence of God is not to be found in this space. It is the farthest part away from the light, and must be viewed as a prison that keeps one away from the upper space (earth and heaven). ${ }^{22}$ What is further important to note is that this is the space in which the human body is found. Perceptions of the body are made in relation to its orientation and location in this worldview perspective, its cosmological space and its boundaries. Is the body located in heaven, earth or Sheol? How is the body faced: up (vertical sphere), down (vertical sphere), east (front), west (back), north (left) or south (right)?

Janowski explains the realm of the dead or the underworld as a counter realm to that of the living. ${ }^{23}$ This "counter-world" or "non-world" shows characteristics that are counter to, or the reverse view of, that of the realm of the living. The first characteristic of the way in which this reverse view is seen, according to Janowski, ${ }^{24}$ is its "position of the world beyond," the space associated with that world. These positions are: the grave (which includes the tomb and any form of a burial place), a specific marked space on the surface of

20 Wyatt, Space and Time, 39.

21 Sutton, "The Rising of Dawn," 558; Prinsloo, "Place, Space and Identity," 9; cf. Bruce J. Malina, Stephan Joubert and Jan van der Watt, A Time Travel to the World of Jesus (Johannesburg: Orion, 1996), 101.

22 Cf. Leland Ryken, James C. Wilhoit, and Tremper Longman III (eds.), Dictionary of Biblical Imagery (Leicester: Inter-Varsity Press, 1998), 349.

23 Bernd Janowski, Arguing with God. A Theological Anthropology of the Psalms. (trans. Armin Siedlecki; Louisville, KY: Westminster John Knox, 2013), 241.

24 Janowski, Arguing with God, 241. 
the earth (such spaces include mountains, islands, edge of the world, and the extreme ends of the earth), a space or region under (downward movement) the earth (water holes, caves, crevices, bottom of lakes, bottom of the sea). The second characteristic of the reverse view, according to Janowski, ${ }^{25}$ is that the realm of the dead is "embellished with regard to its content." The following describes the content: "deterioration or diminishing of earthly existence (Tuat, Sheol, Hades, a shadowlike existence of the dead, semiconscious state...), double afterlife (heaven or eternal punishment)."

\section{Anthropological or embodied space}

In this section, the spatial viewpoint is that from the body; how the body preserves its worldview internally (in the body, i.e., mind, emotions, that which is put into the body) and externally (what is around the body, what comes out of the body and the actions of the body). The starting point for this is the body and not the cosmos.

In studying Old and New Testament man, Malina and Rohrbaugh formulate the body in terms of a "three-zone personality," 26 in terms of which the body is understood in the Mediterranean world in terms of what "anthropologists have called the zones of interpretation." ${ }^{27}$ In the Graeco-Roman world, a human being's body was viewed as consisting of three zones. ${ }^{28}$ First, the zone of emotion-fused thought. This includes will, intellect, judgement, personality and feeling - all understood collectively. The eyes and the heart are especially important in this instance. Secondly, the zone of self-expressive speech. This includes communication, particularly that which is self-revealing. It is about listening and responding. The mouth, ears, tongue, lips, throat, and teeth are especially important in this instance. Thirdly, the zone of purposeful action. This is the zone of external behaviour, or interaction with the environment. The hands, feet, fingers, and legs are especially important in this instance. The human person and human activity can be explained in terms of any particular zone or of all three zones. ${ }^{29}$

According to Coetzee, ${ }^{30}$ a bodily interpretation would view a human body as a three-dimensional container (or rather three-dimensional containers). This

\footnotetext{
25 Janowski, Arguing with God, 242.

26 Bruce J. Malina and Richard L. Rohrbaugh, Social-Science Commentary on the Synoptic Gospels (Minneapolis, MN: Fortress, 2003), 419.

27 Malina and Rohrbaugh, Synoptic Gospels, 419.

28 A zone must also be understood in terms of being a space.

29 Malina and Rohrbaugh, Synoptic Gospels, 419.

30 Johan H. Coetzee, “And Jonah Swam and Swam and Swam: Jonah's Body in Deep Waters," OTE 17 (2004): 521-530 (522). The works of Malina and Rohrbaugh, Synoptic Gospels, and that of Coetzee, "And Jonah Swam," show strong similarities. The difference in their work is mostly due to the use of different terminologies.
} 
means that, when one looks at the body, one must think in terms of containment and boundedness. As a container, certain things such as food, water and air, for example, can be put into the body. Things such as food, water, air and blood, for example, can also be taken or be expelled from the body. This view of containment can also be experienced as a constant physical containment, depending on one's surroundings ${ }^{31}$ For example, moving in and out of buildings; dressing or undressing; entering and exiting cities, and other kinds of bounded spaces. One experiences not only the things one puts into or takes out of one's body, but also the things one puts into or takes out of objects; for example, pouring sugar into a cup or out of a container. According to Coetzee, ${ }^{32}$ the threedimensional enclosure includes the experiences that one can notice: they are observable. ${ }^{33}$ They are spatial and temporal organisations that are the result of a bodily interpretation, more specifically, a "bodily image schema for physical containment". ${ }^{34}$ It is therefore important to understand that this form of interpretation from an in-out orientation must be understood from the perspective of spatial boundedness. The same can be said of an up-down orientation, or a vertical schema. According to Coetzee, ${ }^{35}$ these orientations or interpretations of one's body give coherence and structure to one's experiences as a human being. The consequences of these "recurring experiential image-schematic structure[s] for in-out orientation" 36 include the feeling of protection, resulting from one's resistance to external forces; the feeling of a relative fixity of location or restriction, and the accessibility or inaccessibility to the view of observers. The works of Malina and Rohrbaugh and Coetzee referred to above clearly show that, in order to do a bodily interpretation, one needs to study it from the perspective of space, as it must be understood from the point of view of spatial boundedness.

31 Coetzee, "And Jonah Swam," 522; cf. also Mark Johnson, The Body in the Mind. The Bodily Basis of Meaning, Imagination, and Reason (Chicago, IL: University of Chicago Press, 1987), 21.

32 Coetzee, “And Jonah Swam," 522.

33 According to Johan H. Coetzee, "Where Humans and Animals Meet, Folly Can be Sweet - Jonah's Bodily Experience of Containment the Major Drive Behind his Conduct," OTE 20 (2007): 320-332 (321-322), "[a]11 human experience is incarnated and all meaning, imagination and reasoning to grasp the world as reality, is bodily based and not only an objectivistic activity of the brain. It is through the perceptual organs that we perceive the world around us and it is through the body that we respond to what we perceive. Our emotions and desires are completely bodily based, and are mostly directly linked with our inner body, which contains organs such as the liver, heart, lungs, digestive system, nerve system, blood system, glands, the womb, etcetera. While the body is the centre of one's world and is one's inescapable presence, the body is simultaneously characterized by absence. While listening to a concert, I am not aware of my body."

34 Coetzee, "And Jonah Swam," 522.

35 Coetzee, "And Jonah Swam," 522.

36 Coetzee, "And Jonah Swam," 522-523. 


\section{Darkness as an anthropological space}

Taking these previous remarks into account for the spatial awareness, boundaries and orientation of the human body, one can bring them into relation with the cosmological space, boundaries and orientation of the ancient Near Eastern worldview(s). The view from the body becomes the anthropological space and the view from the worldview becomes the cosmological space. Janowski indicates that, as opposed to the Egyptian worldview where the dead can return to the realm of the living, the Old Testament worldview (heaven, earth, Sheol) does not permit this. ${ }^{37}$ The only exception is that of the supplicant who is saved from death by YHWH; but then the supplicant was never truly dead and in the underworld. The death experienced was only the bodily view of the supplicant (in the mind). Janowski further indicates that the experience of the supplicant of death is in this life: the supplicant is not yet dead, becoming a "living dead." 38 The areas experienced and the characteristics of the afterlife for this context in the living realm are: "grave, dust, prison, cistern, pit, flood, sea, desert, steppe, foothills, and - as a temporal domain - darkness of night." In this context, one needs to discern between the cosmological spatial boundaries and the anthropological spatial boundaries. Within the boundaries of anthropological space, the supplicant who is alive can experience the characteristics of death and the underworld as if he or she were there, which would not be possible within the boundaries of cosmological space where the living cannot enter the realm of the dead.

In Pss 88 and 139, darkness becomes an anthropological space where the one praying the psalms experiences otherworld (underworld) aspects that in the cosmological spatial boundaries would not have been possible. Darkness becomes an anthropological space associated with the realm of the underworld. ${ }^{39}$

\footnotetext{
37 Janowski, Arguing with God, 245.

38 Janowski, Arguing with God, 245.

39 The concept of darkness in the Old Testament is mostly used in terms of a physical understanding of darkness (the absence of light, for example when it is night (Ps 104); or when one has difficulty in seeing where one needs to go (Job 5); a place of hiding for terrors or evildoers or for those placing an ambush (Job 24; 34; Ps 11); a spiritual understanding (battle between good and evil as part of a cosmic conflict, where bad or evil is mostly understood in terms of darkness and that which is good in terms of light - Jer 4); and figurative or symbolic understanding (a different array of metaphors for human experiences - Job 10; Pss 82; 88; 107; 139; Eccl 2; Mic 3). An important topic also associated with darkness is God's power over darkness - Job 34; 38; Ps 139; Ezek 8 (Ryken et al. [eds.], Dictionary of Biblical Imagery, 191-193). In the Book of Psalms, the Hebrew words used for darkness are the following: אפל (noun, Pss 11:2; 91:6); (noun, Pss 18:11; 35:6; 88:12; 18:28; 104:20; 105:28; 107:10; 107:14; 112:4; 139:11; 139:12); חשך hiph. verb, Ps 105:28); מחשכה (noun, Ps 18:11; 82:5; 139:12);
} 


\section{DARKNESS AS AN ANTHROPOLOGICAL SPACE IN PSALMS 88 AND 139}

In the rest of the article, an intertextual comparison is made between Pss 88 and 139 with regard to the themes of death, life and presence of YHWH, in relation to darkness as an anthropological space in these psalms.

\section{$1 \quad$ Imagery of death (Psalm 88), life (Psalm 139) and the underworld}

According to the cosmological worldview, only the dead can enter Sheol, not the living. Thus, for the one praying Ps 88 , he or she must view him-/herself as dead, or in the anthropological space as the living dead. One can see this in the following language where, according to Hopkins, ${ }^{40}$ the psalmist views him/herself as dead: first, in v. 5 ("I am like a man without strength"), literally be translated by "I am (like) a warrior," implying that the warrior has no strength left and is therefore as good as dead; second, in v. 6 ("set apart with the dead"), the idea behind the phrase is that of someone who is freed from any obligation, freed from life; third, in v. 6 ("who are cut off from your hand") means that to be cut of (ניבְְָרו) is to be separated from God, to be dead (cf. $2 \mathrm{Chr}$ 26:21; Ps 31:22; Isa 53:8). In the meta-narrative, the psalmist would then represent the exiles, who are feeling separated from YHWH, therefore dead.

The speaker's life in Ps 88 is, ironically, defined in terms of death. The terms for the underworld become the "shadowy nonexistence that follows life". ${ }^{41}$ The underworld is apparent is terms such as Sheol, the pit, darkness, death and the grave. In many circumstances in this psalm, death and the underworld are understood as one thing or one subject. According to Wendland, ${ }^{42}$ death as a subject in Ps 88 can be seen in the following: Sheol (v. 4); grave (v. 5); the dead (v. 6); corpses lying in the grave (v. 6); whom you remember no more (v. 6); cut off (v. 6); the lowest regions of the pit (v. 7); in the dark places (v. 7); in the watery depths (v. 7); overwhelm... with all your waves (v. 8); me, an appalling sight (v. 9); I am trapped (v. 9); the dead (v. 11); the departed spirits (v. 11); the grave (v. 12); the place of the dead (v. 12); the dark region (v. 13); the land of oblivion (v. 13); on the verge of death (v. 16); numb with pain (v. 16); your terrors destroy me (v. 17); they surround me like water (v. 18); leave me alone in the darkness (v. 19).

Pss 74:20; 88:6; 88:18; 143:3); ערפל (noun, Pss 18:9; 97:2), and חידה (noun, Pss 49:4; 78:2 - usually translated by "riddle," sometimes by "dark saying").

40 Denise D. Hopkins, Psalms, Books 2-3 (WCom 21; Collegeville, MN: Liturgical, 2016), 359.

41 Segal, A New Psalm, 413.

42 Ernst R. Wendland, “'Darkness is My Closest Friend' (Ps 88:18b): Reflections on

the Saddest Psalm in the Psalter," VeEc 37 (2016), a1543. http://dx.doi.org/10.4102/ve.v37i1.1543. 
Briggs and Briggs describe the realm of the dead in Ps 88 with six terms, namely: Sheol, pit, grave, Abaddon, dark place (darkness) and the land of forgetfulness. ${ }^{43}$ Sheol (v. 4) is seen as the realm of the dead or the underworld in the Old Testament. In worldview terms, this is the lowest level on the vertical sphere. ${ }^{44}$ For the psalmist praying this psalm, Sheol would be the final destination after describing in the imagery that follows in the next verses of the psalm (pit, grave, dark place, Abaddon, land of forgetfulness), the downward journey into Sheol. ${ }^{45}$ The pit (vv. 5, 7) in v. 5 describes a journey downward into the space of death and the grave and then even further down into Sheol. ${ }^{46}$ The grave is viewed as a space of entombment (vv. 7, 12), while Abaddon is seen as a term also synonymous with a pit and should not be understood as destruction. Abaddon should rather be understood as the space in Sheol where the wicked are destroyed. The "dark place" (vv. 7, 13, 19) or darkness is seen as a description or rather a characterisation of the realm of the dead or a "subterranean, cavernous region." "Land of forgetfulness" (v. 13) becomes a space where the dead are

43 Briggs and Briggs, Psalms, Vol. 2, 245.

44 C. Hassel Bullock, Psalms, Volume 2: Psalms 73-150 (TTT; Grand Rapids, MI: Baker, 2017), 122. Bullock describes Sheol as the separation between humans and YHWH. The separation involves the argument that communication is no longer possible (v. 11). The fact that the one praying the psalm sees himself as in Sheol, as being a "living dead, causes him to experience total separation from God, to experience a silent God.

45 Janowski, Arguing with God, 225. According to Janowski, "the supplicant's location in Ps 88, which the nouns 'pit' (vv. 4/5, cf. vv. 6/7); 'grave' (vv. 5/6); 'deepest depths', 'dark places' and 'depths [of the sea]' (vv. 6/7) characterise as the underworld, is also reached by the supplicant through a continuous downward movement: The supplicant's life reaches or touches the underworld (vv. 3/4), the petitioner is counted among those who go down to the pit (vv. 4/5), who lie in the grave like the slain (vv. 5/6), and the supplicant sees himself as placed in the deepest depths, in dark places, in depths [of the sea] by YHwh." Briggs and Briggs, Psalms, Vol. 2, 245 describe this journey into the underworld as a metaphor for Israel that is going into exile, becoming a national death as Sheol becomes a metaphor for their place of captivity.

46 For John Goldingay, Psalms, Volume 2: Psalms 42-89 (BCOTWP; Grand Rapids, MI: Baker Academic, 2007), 649 the one praying had no reason to go to the pit, and no reason was given. But in v. 5 the responsibility for the one placing the psalmist in the pit is attributed to YHWH. The relationship seems to have turned from supplicant and God standing next to each other, to that of a relationship that is experiencing a state of confrontation.

47 deClaissé-Walford et al. argue that due to the syntax of v. 19, many translations translate "darkness" as "my companions are in darkness", that could be better translated as "the darkness is my closest friend," thereby retaining the "knowing" in v. 9. This last translation is in keeping with the context of the psalm (deClaissé-Walford et al., The Book of Psalms, 670-671). 
forgotten about in the realm of the living. ${ }^{48}$ The depths (v. 7), breakers (waves or billows) of the sea (v. 8), and the water (v. 17) are seen as further descriptions of the underworld and darkness and describe the terror that is experienced by the one praying the psalm. The "depths" in v. 7 is translated in the Septuagint, Peshitta and the Vulgate as the "shadow of death." 49

In contrast to Ps 88, life imagery and the underworld in Ps 139 are seen in the creation imagery in vv. 13-18 and predominately expressed in bodily imagery. The bodily imagery helps to see that the one praying the psalm sees him-/herself as a living person, in contrast with Ps 88 where the person views him-/herself as dead. In Ps 139, the first instance of imagery mentioned in v. 13 is the kidneys. The kidneys with their surrounding fat were viewed firstly as part of the burnt offering (Exod 29:13, 22; Lev 3:4, 10, 15; 4:9; 8:6, 25). This was seen as part of life. ${ }^{50}$ The second instance is the imagery in v. 13 concerning the womb. Banwell remarks that there are multiple words that are used to describe the womb or belly in the Hebrew language, therefore indicating vagueness about the internal physiology. ${ }^{51}$ When it is used it usually indicates the beginning of life or the beginning of time (Job 1:21; Isa 49:1), or figuratively, the origin of

48 This is the only place where the term is used in the Old Testament. Anderson, Book of Psalms (73-150), 629 states that the land of forgetfulness can be understood as a term for Sheol and a space where the dead are forgotten about by the living (cf. Ps 31:13; Ecc1 9:5). There is a view that the belief that the dead were forgotten, was not subscribed to by all Israelites due to the "practice of necromancy" (Deut 18:11; 1 Sam 28:8-19; Isa 8:19). What is apparent is that the one praying Ps 88 is of the opinion that the dead cannot communicate with the living and therefore it is easy for the living to forget about them, even for YHWH, as he cannot hear their praises (v. 11).

49 An important difference concerning the Masoretic text and the LXX version of Ps 88 is clear in vv. 5-8. The LXX version of these verses can be translated: "(5) I was reckoned with those going down into a pit, I became like a helpless man/person, free among the dead (plural), (6) like casualties/people fatally wounded, cast away/down, sleeping in a grave, (people) of whom you do not think/remember any more; and they were rejected from your hand. (7) They put (past tense) me in a lowest pit, in dark (places) and in (the) shadow of death. (8) Upon me your wrath has been caused to rest/has been fixed, and all your billows/storms/storm winds/hurricanes you have brought on me."

50 The kidneys of various animals were included in burnt offerings to the Lord in conjunction with fellowship (Lev 3:4, 10, 15; 9:19), sin (Exod 29:13; Lev 4:9; 8:16; 9:10), guilt (Lev 7:4), and wave offerings (Exod 29:22; Lev 8:25). Isa 34:6 employs sacrificial imagery in depicting God's bloody judgment of Edom. The Lord's sword is described as being covered with "fat from the kidneys of rams." Cf. Robert B. Chisholm, "כְִִּּיז (kilyâ), kidneys," NIDOTTE 2:656-657. Sometimes the Hebrew word was applied to kernels of grain, because it had the shape of the kidneys (Deut 32:4); cf. Merrill F. Unger, Unger's Bible Dictionary (Chicago, IL: Moody, 1957), 629.

51 Brian O. Banwell, "Womb," New Bible Dictionary ( $4^{\text {th }}$ ed.; ed. I. Howard Marshall et al.; Downers Grove, IL: IVP Academic, 2015), 1247. 
everything or anything (Job 38:29; Ps 110:3). ${ }^{52}$ The bodily (the bones) and creation imagery is further expressed in v. 15, where the petitioner's formation in the depths of the earth is described. ${ }^{53}$ In v. 19 the imagery of blood is also used. ${ }^{54}$ Blood is also understood as life, but in v. 19 it is used in a negative sense and not as part of the creation language.

The first imagery concerning the underworld in Ps 139 is found in the imagery of vv. 7-9. The imagery described is that of the ancient Near Eastern worldview. The spatial orientation presented in this worldview can be understood as vertical (Ps 139:8) and horizontal (Ps 139:9). The vertical sphere can be seen in the three parts: heaven, earth and Sheol. The psalmist flees to the underworld, indicating an anthropological space, because the psalmist is still alive. The second characteristic of the underworld is that YHWH is not present in that realm. In Ps 139:8, the psalmist finds YHWH in the realm indicating an anthropological space of darkness (representing the characteristics of the underworld) and not in a cosmological space. ${ }^{55}$

52 Due to a lack of understanding, the writers of the OT generally attribute the workings of the womb to YHWH as a direct action of care (Job 31:15; Eccl 11:5). Barrenness is attributed to the closing up of the womb. Sometimes it is stated that this is done by YHWH (1 Sam 1:5). It is seen as a great shame to a woman if she cannot bear children (1 Sam 1:6). The first born is the one that opens the womb for the first time and therefore is seen as holy (Exod 13:2; Luke 2:23) (cf. Ryken et al. [eds.], Dictionary of Biblical Imagery, 962).

53 In the Old Testament, the phrase "bone and flesh" signifies the totality of an individual and therefore was seen as the seat of sensation (Job 4:14; 20:11; Jer 20:9); cf. Roland K. Harrison, "Bones," IDB 1:453, and of one's physical strength and health (Job 20:11; 21:24; Prov 3:8; 15:30; Isa 58:11; 66:14; Lam 4:7); cf. Harrison, "Bones," 453; Robert B. Chisholm, "עָצֶצם ('eșem), bone, skin, body, self," NIDOTTE 3:499-500. The bones become a metaphor for restoration in Isa 66:14. Shaking bones are also a metaphor for fear (Job 4:14; Jer 23:9; Hab 3:16). Weakened bones become a metaphor for those that experience physical pain or emotional distress (Job 33:19, 21; Pss 6:2 [3]; 31:10 [11]; 32:3; 38:3 [4]; 42:10 [11]; Lam 1:13; cf. Job 19:20; 30:17, 30; Ps 102:5 [6]) (Chisholm, "עֶֶֶ ('eșem), bone, skin, body, self," 499-500).

54 In popular belief, myths and magical cultic acts, blood is seen as an essential part of the body, as one of the bodily fluids that include blood, sperm, mother's milk, spittle, urine, tears, and perspiration. Blood was seen in ancient times as a secret power that originated from the body and it was therefore identified to a special degree with vitality. When the blood leaves the body of a living creature, life also leaves (Lev 17:14; Deut 12:23; Gen 9:4-6); cf. Benjamin Kedar-Kopfstein, "“ד̣ dām," TDOT 3:234-250 (237). The opposite is also true: that the blood of menstruation, like the bloodshed at birth, points to sexual intercourse, reproduction, and fertility and to the beginning of new life. 55 Hossfeld and Zenger, Psalms 3, 541, are of the opinion that this psalm shatters this traditional view of the underworld that YHWH is not present and cannot be praised there (cf. Job 11:8; Ps 88:6 and Amos 9:2). According to Hossfeld and Zenger, Psalms 3, 541 , this may be an indication of a "threshold of a hope of resurrection in the Old 
The second space of darkness in Ps 139 is the womb. Again, darkness is described in terms of the underworld but instead of finding death, life is found. In vv. 13-18, the one praying the psalm comes and evaluates his or her own creation by YHWH. The imagery depicting the kidneys and the womb is used to describe how the body of the human is made in totality. It happens in the innermost spaces, in the depths (if one thinks in terms of the underworld), the inner body is created to the outward being of a person, hence the imagery of the kidneys. According to Hossfeld and Zenger, ${ }^{56}$ the image is that of the creator as a weaver. In the depths of the earth could imply the underworld or Sheol (cf. Ps 63:10; Isa 44:23; Ezek 26:20; 31:14, 16, 18; 32:18, 24). According to Keel, ${ }^{57}$ the imagery reflects that of mother earth, the inner earth (cf. Job 1:21; Ps 90:2, and the Mother Earth which brings forth man in Ps 139:15). Instead of associating the imagery of the underworld with death, in Ps 139 the imagery is used as a space for life.

\section{The absence (Psalm 88) or presence (Psalm 139) of YHWH}

Briggs and Briggs describe the Sheol in Ps 88:4 as the space of national death when Israel was in exile. ${ }^{58}$ The death of Israel (the exile) separates Israel from YHWH, and in Sheol they experience silence and a separation from the hand of YHWH (v. 6). Sheol is a place where YHWH does not even think of Israel anymore (v.6), an appropriate metaphor as the realm of the dead is also understood as the land of forgetfulness (v. 13). The association with the realm of the dead and silence from YHWH is further emphasised with the use of the dead, shades, ${ }^{59}$ and the understanding that the dead cannot praise YHWH from the realm of the dead (v. 11). ${ }^{60}$ The silence of YHWH is further emphasised in Ps 88, with six rhetorical question in vv. 11-13. All the questions imply negative answers and serve to remind the psalmist that YHWH is a God that is faithful to the living. They confirm that the space of the dead is not where YHWH is worshipped or where God's actions are praised and showed. ${ }^{61}$ YHWH is silent in the space of the dead, of the underworld, but not in the space of the living. These rhetorical questions

Testament." The problem with this statement of Hossfeld and Zenger is that they did not take into account the difference between an anthropological space and a cosmological space.

56 Hossfeld and Zenger, Psalms 3, 541.

57 Othmar Keel, The Symbolism of the Biblical World. Ancient Near Eastern Iconography and the Book of Psalms (trans. Timothy J. Hallett; Winona Lake, IN: Eisenbrauns, 1997), 203.

58 Briggs and Briggs, Psalms, Vol. 2, 245.

59 Shades are understood by Anderson, Book of Psalms (73-150), 628 as the inhabitants of Sheol that are presented only as shadows of their former selves, whole persons, but "only a shadowy replica."

60 Anderson, Book of Psalms (73-150), 628.

61 W. Dennis Tucker Jr. and Jamie A. Grant, Psalms, Volume 2 (NIVAC; Grand Rapids, MI: Zondervan, 2018), 304. 
help the psalmist in the midst of the darkness of this anthropological space that resembles death and the underworld, and this seems to indicate silence from YHWH: that either YHWH will help the psalmist who is alive and presents hope, or the psalmist who is the living dead and who will truly move into death as experienced at the end of v. 19 where darkness becomes the psalmist's closest friend. In vv. 11-13 the memory of a God that helps the living fills the anthropological space of darkness for a moment with hope. Weiser remarks that these verses help one to understand that even in the psalmist's deepest despair, he still remembers God's previous help, showing that even if God is hidden, the psalmist does not want to let go of YHWH. ${ }^{62}$ The hardest part of the suffering of the psalmist, according to Tucker and Grant, ${ }^{63}$ is "the awareness of the source of the suffering" ("you have..." vv. 7, 8, 9). It is the awareness of the role that YHWH plays in his/her current suffering and more by the fact that there is no response from YHWH. According to Brueggemann and Bellinger, ${ }^{64}$ the rhetorical questions of the psalmist in vv. 11-13 play another possible function, that of making YHWH aware of the psalmist so as to be sure not to send the psalmist to Sheol before his/her time. If YHWH were to send the psalmist to Sheol, YHWH would have one less worshipper, as the psalmist would not be able to worship YHWH in the underworld. Terrien goes further, explaining that this text is there to mock and tease YHWH, in order to bring God to action. ${ }^{65}$ In the end it is clear that even this did not cause YHWH to come out of silence. ${ }^{66}$

According to Thornhill, ${ }^{67}$ in addition to the psalmist moving into this grave, this burial at the hand of YHWH, his anger oppresses the psalmist like the breaking of waves on the shore. In his/her final complaint of this section, the psalmist notes the isolation he/she has experienced at YHWH's hand. His/her companions have been taken away and now loathe him/her. He/she is "shut in" (vv. 8-9), perhaps in the sense of being socially isolated, or referring back to his/her "condition as one confined to the grave." His/her misery has resulted in the weariness of his/her entire being. YHWH is not to be found.

According to Maré, 68 in Ps 88:5-6, "The psalmist has been set loose amongst the dead." Verse 6 is therefore highly ironic, and also extremely tragic. "The psalmist is 'free' from everything that makes life meaningful and enjoyable; he is 'free' to be as good as dead. He compares himself with those

\footnotetext{
62 Artur Weiser, The Psalms (trans. Herbert Hartwell; OTL; London: SCM, 1979, 586.

63 Tucker and Grant, Psalms, Volume 2, 303.

64 Walter Brueggemann and William H. Bellinger Jr., Psalms (NCBC; New York,

NY: Cambridge University Press, 2015), 380.

65 Terrien, Psalms, 628.

66 Cf. Brueggemann and Bellinger, Psalms, 381.

67 Thornhill, “A Theology of Psalm 88," 51-52.

68 Maré, "Psalm 88 and the Life of Faith," 183.
} 
who are already in their graves, and worst of all, YHWH doesn't remember them anymore. He has been cut off from YHWH's hand, no longer in his presence or even in his memories... He is close to the netherworld, far away from the land of the living, and even worse; far away from YHWH."

Light and darkness in Ps 139:11-12 are viewed by many as the opposite of good and evil or that light is "good" and darkness is "bad." Brueggemann and Bellinger interpret the light and darkness in the context that even if the psalmist is surrounded by darkness, the presence of YHWH will not leave the psalmist and YHWH sees all. ${ }^{69}$ They interpret this as protective imagery. DeClaissé-Walford explains the darkness as the antithesis of light as part of a realm of uncertainty and fear and brings the terms in relation to the creation in Gen $1 .^{70}$ Although she brings vv. 11-12 into relation with the creation, she also concludes that YHWH is there with the one praying no matter where he goes, interpreting it as protective imagery. These interpretations seem logical in relation to other texts in the Old Testament (cf. Job 12:22; Ps 35:6; 88:6, 12; 107:10, 14), but in relation to the previous verses (7-10), they must be viewed in spaces where the one praying the psalm is attempting to hide from YHWH. Hossfeld and Zenger explain that darkness (night) and light (day) are part of creation theology and that darkness reflects the elements of "chaos, disorder and nonexistence where the petitioner can disappear or fall back." ${ }^{11}$ Even there he cannot hide from YHWH. The presence of YHWH is so overwhelming for the psalmist in Ps 139 that he/she is willing to flee to the underworld (vv. 8-9), to where God in the cosmological worldview would not be present, but is present in the anthropological space. The same applies to darkness (vv. 11-12): YHWH is not supposed to be there according to cosmological boundaries, but in the space of darkness as an anthropological space, God is present.

The imagery of the hand in Ps 139:10 differs from its use in other psalms in the book of Psalms. Generally, the imagery of the hand refers to imagery that indicates God's judgment (Ps 32:4), assistance and/or deliverance (Ps 108:6-7), liberation (Ps 118:15-16) or to indicate one's position in regard to YHWH (Pss $109: 31 ; 110: 1 ; 121: 5)$. Psalm 139:10 is the only place in the psalter where YHWH's hand is used to lead someone. ${ }^{72}$ One is therefore inclined to interpret this imagery of the hand in Ps 139:10 as positive imagery. Hossfeld and Zenger interpret this verse in the sense that, although one tends to view YHWH's hand and specifically his right hand, as an image of guidance and saving presence as in Ps 138:7, one needs to interpret this verse in relation to the previous and following verses where it shows that YHWH's presence is viewed negatively. ${ }^{73}$

69 Brueggemann and Bellinger, Psalms, 583.

70 deClaissé-Walford et al., Book of Psalms, 964.

71 Hossfeld and Zenger, Psalms 3, 541.

72 Tucker, Constructing and Deconstructing Power, 149-151.

73 Hossfeld and Zenger, Psalms 3, 541. 
YHWH's grasp or hold on the psalmist is almost suffocating (as if the hand is pressing down on the petitioner). Yet, while the hand of God is not found in Ps 88, in Ps 139 the presence of YHWH, as a God that leads the psalmist even in darkness, is found.

\section{CONCLUSION}

Darkness as an anthropological space plays an important role in the understanding of Pss 88 and 139, and also in the meta-narrative of the Book of Psalms, where darkness as an anthropological space uses characteristics of the cosmological space's (ancient Near Eastern worldview) understanding of the underworld where the dead live and where YHWH is absent, and the realm of the living, earth, where YHWH is present. This can be illustrated as follows:

\begin{tabular}{|c|c|c|c|}
\hline $\begin{array}{l}\text { Cosmological } \\
\text { space }\end{array}$ & \multicolumn{2}{|c|}{ Anthropological space } & $\begin{array}{l}\text { Cosmological } \\
\text { space }\end{array}$ \\
\hline $\begin{array}{l}\text { The realm of the } \\
\text { living earth }\end{array}$ & \multicolumn{2}{|c|}{$\begin{array}{l}\text { Darkness as a space that resembles the } \\
\text { cosmological space of the underworld, } \\
\text { but shows characteristics of the } \\
\text { cosmological space of the living and } \\
\text { the underworld (Sheol, deepest pit, } \\
\text { darkness, grave, sea, watery depths, } \\
\text { land of forgetfulness) }\end{array}$} & $\begin{array}{l}\text { The realm of the } \\
\text { dead, Sheol } \\
\text { (underworld) }\end{array}$ \\
\hline \multirow[b]{2}{*}{$\begin{array}{l}\text { - Humans live } \\
\text { - God leads and } \\
\text { protects } \\
\text { - God is present } \\
\text { - Can } \\
\text { communicate } \\
\text { with and praise } \\
\text { YHWH } \\
\text { - Cultivated land }\end{array}$} & Psalm 88 & Psalm 139 & \multirow[b]{2}{*}{$\begin{array}{l}\text { - Humans are dead } \\
\text { - YHWH does not } \\
\text { lead and protect } \\
\text { - YHWH is not } \\
\text { present } \\
\text { - Cannot } \\
\text { communicate } \\
\text { with and praise } \\
\text { YHWH (silent) } \\
\text { - Cannot return } \\
\text { from this land }\end{array}$} \\
\hline & $\begin{array}{l}\text { - Psalmist sees } \\
\text { him-/herself as } \\
\text { dead, but is alive } \\
\text { - YHWH does not } \\
\text { lead and protect } \\
\text { - YHWH is not } \\
\text { present, is silent } \\
\text { - Is in the world } \\
\text { of the living and } \\
\text { can return, but } \\
\text { the psalmist sees } \\
\text { him-/herself in } \\
\text { the land of the } \\
\text { dead, and feels } \\
\text { there is no } \\
\text { return }\end{array}$ & $\begin{array}{l}\text { - Psalmist sees } \\
\text { him-/herself as } \\
\text { alive } \\
\text { - YHWH leads and } \\
\text { protects } \\
\text { - YHWH is } \\
\text { present, not } \\
\text { silent and is } \\
\text { found } \\
\text { - Is in the world } \\
\text { of the living and } \\
\text { can return, } \\
\text { psalmist sees } \\
\text { him-/herself in } \\
\text { the land of the } \\
\text { dead, and does } \\
\text { return }\end{array}$ & \\
\hline
\end{tabular}

In the meta-narrative of the Book of Psalms, Ps 88 presents an anthropological space of darkness where the one praying the psalm seeks YHWH's help and deliverance from death and Sheol. In this story, the psalmist views him-/herself as dead (the living dead - Ps 88:5,6) and in darkness (Sheol - v. 4; Abaddon - v. 5; grave - vv. 7, 12; dark places - vv. 7, 13, 19; land of 
forgetfulness - v. 13), the realm where YHWH is not present and he/she seeks deliverance, but does not find it. This is the situation of Israel in the time of exile. In Ps 139, darkness as a space is used by the psalmist to describe the difficult relationship that exists between the psalmist and $\mathrm{YHWH}$, with the psalmist trying to flee from YHWH's presence, going to the darkness (and Sheol) where YHWH is not to be found, but finding YHWH. The elements of the cosmological space of the underworld (Ps 139:8-9, 11-12) are used, but they are mixed with the living world, creating an anthropological space where life is described and created (Ps 139:13-14) in a space of darkness. In the story of Israel, Ps 139 describes the difficult situation of rebuilding and restoration, after a time of exile. The relationship that was broken between YHWH and Israel (the psalmist) that is rebuilt and needs to be protected from the wicked (Ps 139:20-21) is thus described.

\section{BIBLIOGRAPHY}

Allen, Leslie C. Psalms 101-50, revised. Word Biblical Commentary 21. Nashville, TN: Thomas Nelson, 2002.

Anderson, Arnold A. The Book of Psalms (73-150). New Century Bible Commentary. Grand Rapids, MI: Eerdmans, 1981.

Banwell, Brian O. "Womb." Page 1247 in New Bible Dictionary. $4^{\text {th }}$ ed. Edited by I. Howard Marshall, Alan Millard, James Packer and Donald Wiseman. Downers' Grove, IL: IVP Academic, 2015.

Bellinger, William H., Jr. Psalms. A Guide to Studying the Psalter. $2^{\text {nd }}$ ed. Grand Rapids, MI: Baker Academic, 2012.

Botha, Phil J. "Psalm 108 and the Quest for Closure." Old Testament Essays 23 (2010): 574-596.

Briggs, Charles A. and Emily G. Briggs, The Book of Psalms, Vol. 2. International Critical Commentary. Edinburgh: T\&T Clark, 1969.

Brueggemann, Walter and Bellinger, William H., Jr. Psalms. New Cambridge Bible Commentary. New York, NY: Cambridge University Press, 2015.

Bullock, C. Hassell. Psalms, Volume 2: Psalms 73-150. Teach the Text. Grand Rapids, MI: Baker, 2017.

Childs, Brevard S. "Orientation.” Page 608 in vol. 3 of The Interpreter's Dictionary of the Bible. Edited by George. A. Buttrick. New York, NY: Abingdon, 1962.

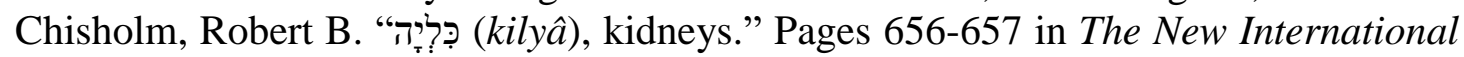
Dictionary of Old Testament Theology and Exegesis, Volume 2. Edited by Willem A. Van Gemeren. Grand Rapids, MI: Zondervan, 1997.

Chisholm, Robert B. "עֶצֶם ('eșem), bone, skin, body, self." Pages 499-500 in The New International Dictionary of Old Testament Theology and Exegesis, Volume 3. Edited by Willem A. Van Gemeren. Grand Rapids, MI: Zondervan, 1997.

Coetzee, Johan H. "And Jonah Swam and Swam and Swam: Jonah's Body in Deep Waters." Old Testament Essays 17 (2004): 521-530.

Coetzee, Johan H. "Where Humans and Animals Meet, Folly Can be Sweet - Jonah's Bodily Experience of Containment the Major Drive Behind his Conduct." Old Testament Essays 20 (2007): 320-332. 
deClaissé-Walford, Nancy. Reading from the Beginning. The Shaping of the Hebrew Psalter. Macon, GA: Mercer University Press, 1997.

deClaissé-Walford, Nancy. Introduction to the Psalms. A Song from Ancient Israel. St. Louis, MO: Chalice, 2004.

deClaissé-Walford, Nancy. "The Canonical Approach to Scripture and the Editing of the Hebrew Psalter." Pages 1-11 in The Shape and Shaping of the Book of Psalms. The Current State of Studies. Edited by Nancy deClaisse-Walford. Ancient Israel and Its Literature 20. Atlanta, GA: Society of Biblical Literature, 2014. https:// doi.org/10.2307/j.ctt9qh23j.5.

deClaissé-Walford, Nancy. "The Meta-Narrative of the Psalter." Pages 363-376 in The Oxford Handbook of the Psalms. Edited by William P. Brown, Oxford: Oxford University Press, 2014. https://doi.org/10.1093/oxfordhb/9780199783335.013. $\underline{024}$.

deClaissé-Walford, Nancy, Rolf A. Jacobson, and Beth LaNeel Tanner. The Book of Psalms. New International Commentary on the Old Testament. Grand Rapids, MI: Eerdmans, 2014.

Dahood, Mitchell. Psalms III: 101-150. Anchor Bible 17A. Garden City, NY: Doubleday, 1970.

Drinkard, Joel F. "East." Page 248 in vol. 2 D-G of The Anchor Bible Dictionary. Edited by David N. Freedman. New York, NY: Doubleday, 1992.

Drinkard, Joel F. "North." Pages 1135-1136 in vol. 4 K-N of The Anchor Bible Dictionary. Edited by David. N. Freedman. New York, NY: Doubleday, 1992.

Drinkard, Joel F. "Right, Right Hand." Page 724 in vol. 5 O-Sh of The Anchor Bible Dictionary. Edited by David N. Freedman. New York, NY: Doubleday, 1992.

Drinkard, Joel F. "South." Page171 in vol. $6 \mathrm{Si}-\mathrm{Z}$ of The Anchor Bible Dictionary. Edited by David N. Freedman. New York, NY: Doubleday, 1992.

Drinkard, Joel F. "West." Page 908 in vol. 6 Si-Z of The Anchor Bible Dictionary. Edited by David N. Freedman. New York, NY: Doubleday, 1992.

Gerstenberger, Erhard S. Psalms, Part 2, and Lamentations. Forms of Old Testament Literature 15. Grand Rapids, MI: Eerdmans, 2001.

Goldingay, John. Psalms, Volume 2: Psalms 42-89. Baker Commentary on the Old Testament Wisdom and Psalms. Grand Rapids, MI: Baker Academic, 2007.

Gottwald, Norman. The Hebrew Bible. A Socio-Literary Introduction. Philadelphia, PA: Fortress, 1987.

Harrison, Roland K. "Bones." Page 453 in The Interpreter's Dictionary of the Bible, Volume 1. Edited by George A. Buttrick. New York, NY: Abingdon, 1962.

Hopkins, Denise D. Psalms, Books 2-3. Wisdom Commentary 21. Collegeville, MN: Liturgical, 2016.

Hossfeld, Frank-Lothar and Erich Zenger. Psalms 3: A Commentary on Psalms 101150. Translated by Linda M. Maloney. Hermeneia. Minneapolis, MN: Fortress, 2011.

Howard, David M., Jr. The Structure of Psalms 93-100. Biblical and Judaic Studies from the University of California, San Diego 5. Winona Lake, IN: Eisenbrauns, 1997.

Janowski, Bernd. Arguing with God. A Theological Anthropology of the Psalms. Translated by Armin Siedlecki. Louisville, KY: Westminster John Knox, 2013.

Johnson, Mark. The Body in the Mind. The Bodily Basis of Meaning, Imagination, and Reason. Chicago, IL: University of Chicago Press, 1987. 
Kedar-Kopfstein, Benjamin. " "דָ dām." Pages 234-250 in Theological Dictionary of the Old Testament, Volume 3. Edited by Johannes G. Botterweck and Helmer Ringgren. Grand Rapids, MI: Eerdmans, 1978.

Keel, Othmar. The Symbolism of the Biblical World. Ancient Near Eastern Iconography and the Book of Psalms. Translated by Timothy J. Hallett. Winona Lake, IN: Eisenbrauns, 1997.

Koptak, Paul E. "Intertextuality." Pages 325-332 in Dictionary of the Old Testament: Wisdom, Poetry \& Writings. Edited by Tremper Longman III and Peter Enns. Nottingham: Inter-Varsity Press, 2008.

Kraus, Hans-Joachim. Psalms 60-150. A Commentary. Translated by Hilton C. Oswald. Continental Commentaries. Minneapolis, MN: Augsburg Fortress, 1989.

Malina, Bruce J., Stephan Joubert, and Jan van der Watt. A Time Travel to the World of Jesus. Johannesburg: Orion, 1996.

Malina, Bruce J. and Richard L. Rohrbaugh. Social-Science Commentary on the Synoptic Gospels. Minneapolis, MN: Fortress, 2003.

Maré, Leonard P. "Creation Theology in Psalm 139." Old Testament Essays 23 (2010): 693-707.

Maré, Leonard P. "Facing the Deepest Darkness of Despair and Abandonment: Psalm 88 and the Life of Faith." Old Testament Essays 27 (2014): 177-188.

McCann, J Clinton, Jr. "The Shape and Shaping of the Psalter: Psalms in Their Literary Context." Pages 350-362 in The Oxford Handbook of the Psalms. Edited by William P. Brown, Oxford: Oxford University Press, 2014. https://doi.org/10. 1093/oxfordhb/9780199783335.013.023.

Peels, Eric. "I Hate Them With Perfect Hatred (Psalm 139:21-22)." Tyndale Bulletin 59 (2008): 35-51.

Prinsloo, Gert T. M. Hebreeus is Kinderspeletjies, Volume 2. Die Analise en Interpretasie van Bybels-Hebreeuse Tekste. Pretoria: Universiteit van Pretoria, 2008.

Prinsloo, Gert T. M. "Place, Space and Identity in the Ancient Mediterranean World: Theoretical Considerations and Practical Application with Reference to the Book of Jonah." Pages 3-25 in Constuction of Space V: Place, Space and Identity in the Ancient Mediterranean World. Edited by Gert T. M. Prinsloo and Christl M. Maier. Library of Hebrew Bible / Old Testament Studies 576. London: T\&T Clark, 2013.

Ryken, Leland, James C. Wilhoit, and Tremper Longman III (eds.). Dictionary of Biblical Imagery. Leicester: Inter-Varsity Press, 1998.

Segal, Benjamin J. A New Psalm. The Psalms as Literature. Jerusalem: Gefen, 2013.

Seybold, Klaus. Introducing the Psalms. Translated by R. Graeme Dunphy. Edinburgh: T\&T Clark, 1990.

Sutton, Lodewyk. "The Rising of Dawn - An Investigation of the Spatial and Religious Background of 'Dawn' in Psalm 139:7-12.” Journal for Semitics 20 (2011): 546561.

Terrien, Samuel. The Psalms: Strophic Structure and Theological Commentary. Eerdmans Critical Commentaries. Grand Rapids, MI: Eerdmans, 2003.

Thornhill, Chadwick A. “A Theology of Psalm 88.” Evangelical Quarterly 87 (2015): 45-57. 
Tucker, W. Dennis, Jr. Constructing and Deconstructing Power in Psalms 107-150. Ancient Israel and Its Literature 19. Atlanta: SBL Press, 2014. https://doi.org/ 10.2307/j.ctt9qh23j.17.

Tucker, W. Dennis, Jr. "The Role of the Foe in Book 5: Reflections on the Final Composition of the Psalter." Pages 179-191 in The Shape and Shaping of the Book of Psalms. The Current State of Scholarship. Edited by Nancy deClaisséWalford. Ancient Israel and its Literature 20. Atlanta, GA: SBL Press, 2014.

Tucker, W. Dennis, Jr. and Jamie A. Grant. Psalms, Volume 2. New International Version Application Commentary. Grand Rapids, MI: Zondervan, 2018.

Unger, Merrill F. Unger's Bible Dictionary. Chicago: Moody, 1957.

Wendland, Ernst R. “'Darkness is My Closest friend' (Ps 88:18b): Reflections on the Saddest Psalm in the Psalter." Verbum et Ecclesia 37 (2016), a1543. https://doi. org/10.4102/ve.v37i1.1543.

Weiser, Artur. The Psalms. Translated by Herbert Hartwell. Old Testament Library. London: SCM, 1979.

Wyatt, Nicolas. Space and Time in the Religious Life of the Near East. Sheffield: Sheffield Academic Press, 2001.

Zenger, Erich. "The Composition and Theology of the Fifth Book of Psalms, Psalms 107-145." Journal for the Study of the Old Testament 80 (1998): 77-102. https:// doi.org/10.1177/030908929802308005.

Zenger, Erich (ed.). The Composition of the Book of Psalms. Bibliotheca Ephemeridum Theologicarum Lovaniensium 238. Leuven: Peeters, 2010.

Dr Lodewyk Sutton, Old and New Testament Studies, Faculty of Theology and Religion, University of the Free State, Bloemfontein, South Africa, Email suttonl@ufs.ac.za. ORCID: https://orcid.org/0000-0001-5502-5932. 